Hydrogen and Water: An

Engineering, Economic and

Environmental Analysis

A. J. Simon, W. Daily, R. G. White

January 6, 2010 
This document was prepared as an account of work sponsored by an agency of the United States government. Neither the United States government nor Lawrence Livermore National Security, LLC, nor any of their employees makes any warranty, expressed or implied, or assumes any legal liability or responsibility for the accuracy, completeness, or usefulness of any information, apparatus, product, or process disclosed, or represents that its use would not infringe privately owned rights. Reference herein to any specific commercial product, process, or service by trade name, trademark, manufacturer, or otherwise does not necessarily constitute or imply its endorsement, recommendation, or favoring by the United States government or Lawrence Livermore National Security, LLC. The views and opinions of authors expressed herein do not necessarily state or reflect those of the United States government or Lawrence Livermore National Security, LLC, and shall not be used for advertising or product endorsement purposes.

This work performed under the auspices of the U.S. Department of Energy by Lawrence Livermore National Laboratory under Contract DE-AC52-07NA27344. 


\title{
Hydrogen and Water: \\ An Engineering, Economic and Environmental Analysis
}

\author{
Aaron J. Simon \\ William Daily \\ Richard G. White \\ Lawrence Livermore National Laboratory \\ January, 2010
}




\section{Acknowledgements}

We would like to thank Vince Tidwell and his team at Sandia National Laboratories for allowing us to be among the first external users of their Decision Support Model for Integrated Water-Energy Planning. Supporting pre-production software is no easy task, yet their model proved to be a crucial component of the regional water stress analysis. We would also like to thank Erik Schuster and his team at the National Energy Technology Laboratory for compiling much of the data that went into the Sandia model. Darlene Steward and Mark Ruth of the National Renewable Energy Laboratory have been important partners in tying this analysis to the existing frameworks of $\mathrm{H} 2 \mathrm{~A}$ and the MSM.

This work was supported by Fred Joseck, Technology Development Manager at the Fuel Cells and Infrastructure Technologies Program in the Department of Energy's Office of Energy Efficiency and Renewable Energy. 


\section{Executive Summary}

Water is a key feedstock to the hydrogen production process. Water is a process input (some, if not all hydrogen will come from the $\mathrm{H}_{2}$ in $\mathrm{H}_{2} \mathrm{O}$ ), and at least as importantly, water is used to cool the process equipment that will make hydrogen. Water is also an input to other lifecycle steps, particularly the generation of electricity.

Water is abundant. Even in areas expected to achieve high levels of hydrogen vehicle market penetration, water use for hydrogen production is unlikely to be more than $1.5 \%$ of the local freshwater supply. Other uses of water such as agriculture and power production make hydrogen's anticipated use appear trivial.

Water is inexpensive. Under reasonable economic assumptions, the cost of purchasing water, water treatment (including capital costs) and disposing of wastewater is expected to comprise less than $\$ 0.09$ per kg hydrogen.

However, it is still important for stakeholders in the hydrogen industry to understand the engineering, economic, environmental and policy issues related to water. In particular, this report addresses two key areas:

\section{Technology Options}

There are two widely available options for water treatment: reverse osmosis and ion exchange. Similarly, there are two classes of process cooling: cooling towers and dry cooling. In general, these technologies face tradeoffs in cost, power consumption, total water input ("withdrawal") and wastewater generation ("discharge"). This report identifies the water purchase and discharge costs at which it makes sense to transition from a low-cost, high-withdrawal technology to a high-cost, lowwithdrawal technology.

\section{Water Resources}

In order to anticipate the need for different water strategies, the stress on water resources and state of water prices in localities of interest to the hydrogen industry were analyzed. It was found that water purchase and disposal prices are not high enough anywhere to be a factor in early-stage hydrogen deployment, but that many locations exhibit risk factors (higher-than-average prices, low industrial water use, or high water stress) that warrant special attention. 


\section{Introduction}

The multi-year program plan for the Department of Energy's Hydrogen and Fuel Cells Technology Program (USDOE, 2007a) calls for the development of system models to determine economic, environmental and cross-cutting impacts of the transition to a hydrogen economy. One component of the hydrogen production and delivery chain is water; water's use and disposal can incur costs and environmental consequences for almost any industrial product.

It has become increasingly clear that due to factors such as competing water demands and climate change, the potential for a water-constrained world is real. Thus, any future hydrogen economy will need to be constructed so that any associated water impacts are minimized. This, in turn, requires the analysis and comparison of specific hydrogen production schemes in terms of their water use.

Broadly speaking, two types of water are used in hydrogen production: process water and cooling water. In the production plant, process water is used as a direct input for the conversion processes (e.g. steam for Steam Methane Reforming $\{\mathrm{SMR}\}$, water for electrolysis). Cooling water, by distinction, is used indirectly to cool related fluids or equipment, and is an important factor in making plant processes efficient and reliable. Hydrogen production further relies on water used indirectly to generate other feedstocks required by a hydrogen plant. This second order indirect water is referred to here as "embedded" water. For example, electricity production uses significant quantities of water; this "thermoelectric cooling" contributes significantly to the total water footprint of the hydrogen production chain. A comprehensive systems analysis of the hydrogen economy includes the aggregate of the water intensities from every step in the production chain including direct, indirect, and embedded water.

Process and cooling waters have distinct technical quality requirements. Process water, which is typically high purity (limited dissolved solids) is used inside boilers, reactors or electrolyzers because as it changes phase or is consumed, it leaves very little residue behind. Pre-treatment of "raw" source water to remove impurities not only enables efficient hydrogen production, but also reduces maintenance costs associated with component degradation due to those impurities. Cooling water has lower overall quality specifications, though it is required in larger volumes. Cooling water has distinct quality requirements aimed at preserving the cooling equipment by reducing scaling and fouling from untreated water.

At least as important as the quantity, quality and cost of water inputs to a process are the quantity, quality and cost of water discharge. In many parts of the world, contamination from wastewater streams is a far greater threat to water supply than scarcity or drought (Brooks, 2002). Wastewater can be produced during the pre-treatment processes for process and cooling water, and is also sometimes generated during the hydrogen production and cooling operations themselves. Wastewater is, by definition, lower quality than supply water. Municipal wastewater treatment facilities can handle some industrial wastewaters; others must be treated on-site or recycled. Any of these options can incur additional cost and/or complexity. 
DOE's " $\mathrm{H} 2 \mathrm{~A}$ " studies have developed cost and energy intensity estimates for a variety of hydrogen production pathways. These assessments, however, have not focused on the details of water use, treatment and disposal. As a result, relatively coarse consumption numbers have been used to estimate water intensities. The water intensity for hydrogen production ranges between 1.5-40 gallons per kilogram of hydrogen, including the embedded water due to electricity consumption and considering the wide variety of hydrogen production, water treatment, and cooling options. Understanding the consequences of water management choices enables stakeholders to make informed decisions regarding water use.

Water is a fundamentally regional commodity. Water resources vary in quality and quantity from region to region, but because of its ubiquity, and because of the enormous volumes in which it is used, there is relatively little long-distance trade in water. As a consequence, water management policies are highly regionalized. Therefore, projecting the water footprint of a given hydrogen facility requires site-specific knowledge of available water resources. Only in the most constrained regions, water may be drawn from remote sources and conveyed long distances by pipeline or aqueduct. Regional water conditions can change over time as fresh and ground water levels change, competing demands become more acute, and shifts in historical climatic patterns take hold. For hydrogen plant stakeholders, a robust development and operating plan would incorporate these regional issues.

This report, and the accompanying analysis at DOE's hydrogen program, seeks to provide information to policymakers, planners and engineers regarding water's impacts on hydrogen deployment, and hydrogen's impacts on regional water resources. 


\section{Water Treatment and Disposal Technologies}

Each of the steps in the hydrogen production, delivery and use chain has an impact on water resources. At the lowest level, fuel vendors and process engineers need detailed knowledge of technology options for process, cooling and waste water treatment at the hydrogen production plant. At the highest level, policymakers should understand the total water implications of hydrogen as they make decisions regarding energy infrastructure. Figure 1 shows a conceptual Sankey diagram of the hydrogen economy with both energy and water inputs. Water withdrawal, consumption and return are affected by the total amount of hydrogen produced, the total amount of electricity consumed in the entire chain and the technologies used to treat water in the hydrogen production process and the electricity production process.

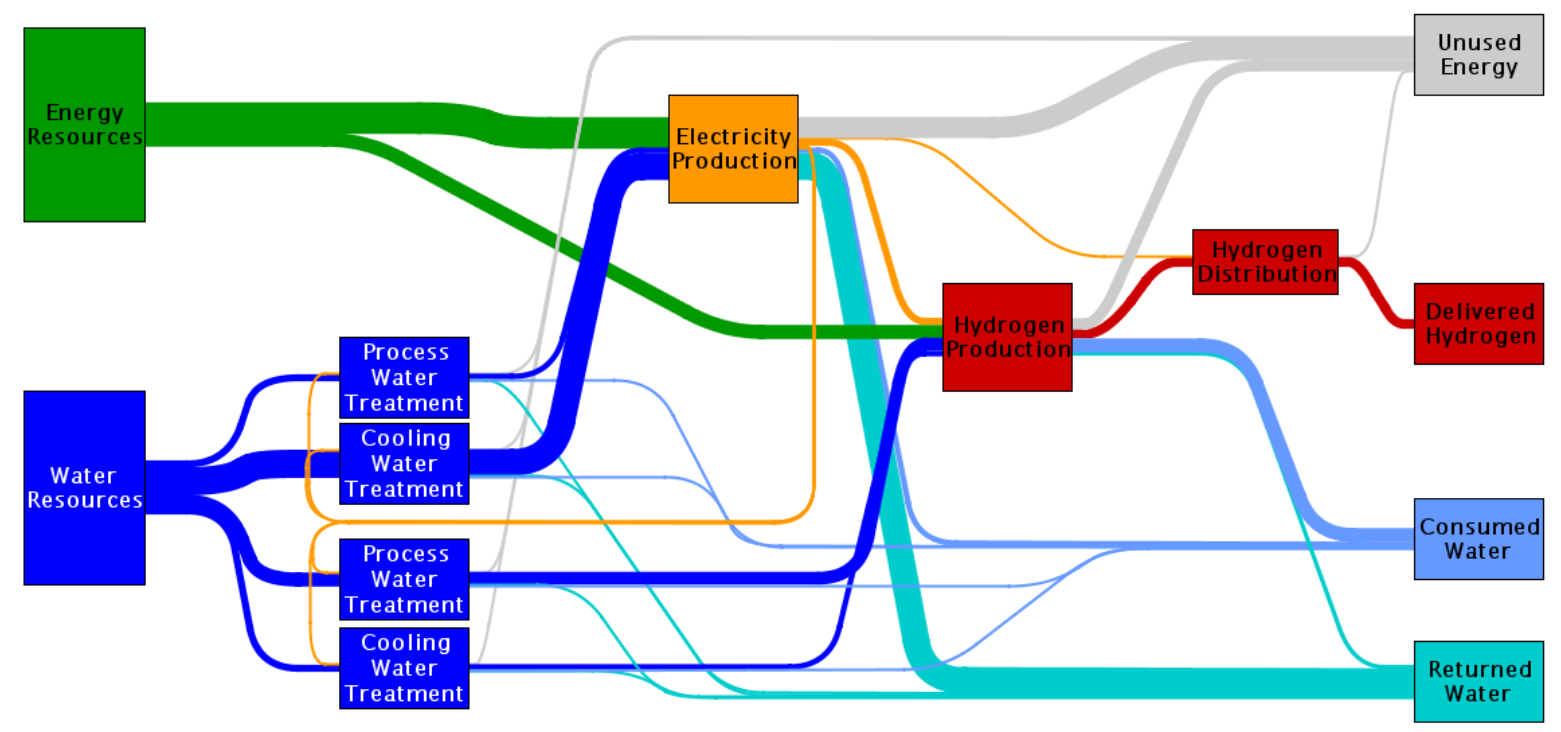

Figure 1: Sankey diagram showing energy and water inputs into the hydrogen value chain. Flow proceeds from left to right through the boxes that represent unit operations. Water use/production in energy extraction and energy use in water extraction are not shown.

Not shown is the water withdrawal, production, consumption and discharge during energy resource extraction. The water cost of extraction and processing of hydrocarbon and nuclear materials is not considered in this analysis because the economic value of hydrocarbon and nuclear fuels has resulted in the development of infrastructure that enables their long-distance trade and water is generally extracted relatively close to its point of use. The supply constraints on water for hydrogen production are therefore decoupled from the supply constraints on water for hydrocarbon or nuclear fuel extraction. This is true to a much lesser extent for electricity; although the United States does have a nationally connected electrical grid, the distances over which most electricity is transported are much more comparable to water networks than they are to fuel markets. 
In this report, the most likely options for hydrogen production, process cooling and water treatment are discussed. The accompanying analysis, which links to DOE's H2A (USDOE 2003) is built to handle a broader range of technologies.

In this report, options for hydrogen production, process cooling and water treatment are presented discussed for comparison purposes. The accompanying analysis, which links to DOE's H2A (USDOE 2003) is built to handle a broader range of technologies.

Hydrogen Production:

The two hydrogen production technologies that are most likely to be adopted in the coming decades are those that are already relatively well developed: Steam Methane Reforming (SMR) and Electrolysis.

Both of these technologies could be used at central station hydrogen production facilities or at forecourt production and dispensing stations. The process and cooling water requirements vary with both technology and scale. In this analysis, it is assumed that the hydrogen producer operates a standalone hydrogen facility and is therefore responsible for all of the process, cooling and wastewater management. In the case of a hydrogen production facility co-located with other industrial operations (petroleum refining, for instance), infrastructure for process and cooling water may already exist. In that case, the total cost of water management to the hydrogen production process will almost certainly be lower than the costs estimated here.

\section{Water Treatment Technologies:}

It is assumed that all water inputs to a hydrogen production process originate from a single resource. Large operations often use surface water (from a lake or river) as their primary water resource, but some are supplied with groundwater, saline (ocean) water or municipal water. Small (forecourt) operations will likely use municipal water supplies or reclaimed water which is not suitable for drinking, but has already been centrally treated to remove toxins and pathogens. Contaminant levels in water supplies can range between 200 and 1000 parts per million (ppm) total dissolved solids (TDS) for surface and municipal water, and are much higher for ground and saline water.

There are several water treatment technologies (flash evaporators, micro/nano filtration, ion-exchange, reverse osmosis, etc.) applicable for cooling and $\mathrm{H}_{2}$ process waters. The best method(s) would utilize coexisting plant processes and readily available energy

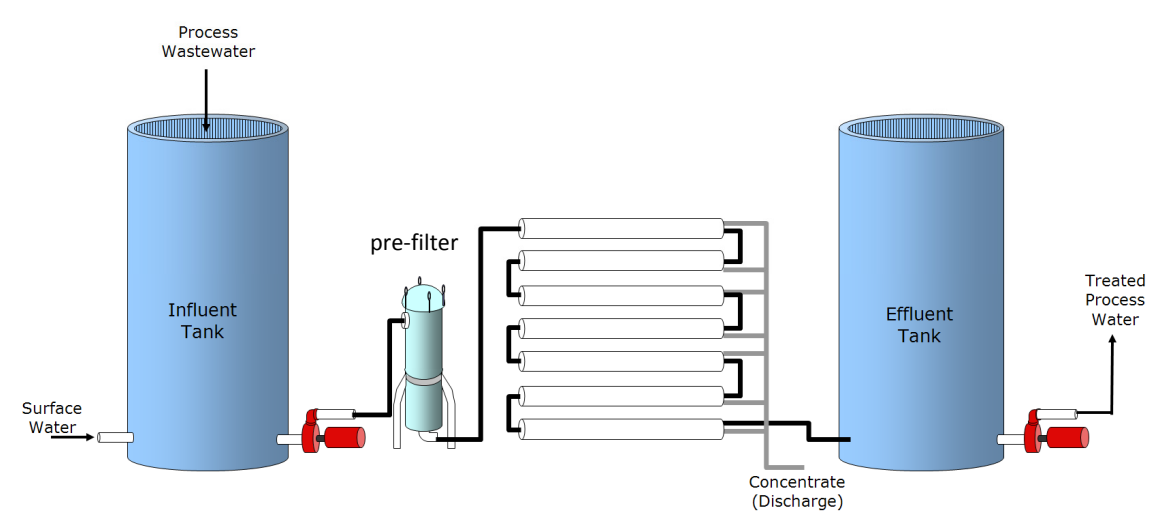

Figure 2: Reverse osmosis treatment of process water. Because this is a continuous flow system, contaminants cannot be allowed to build up in the system, so they are rejected in the concentrate. 


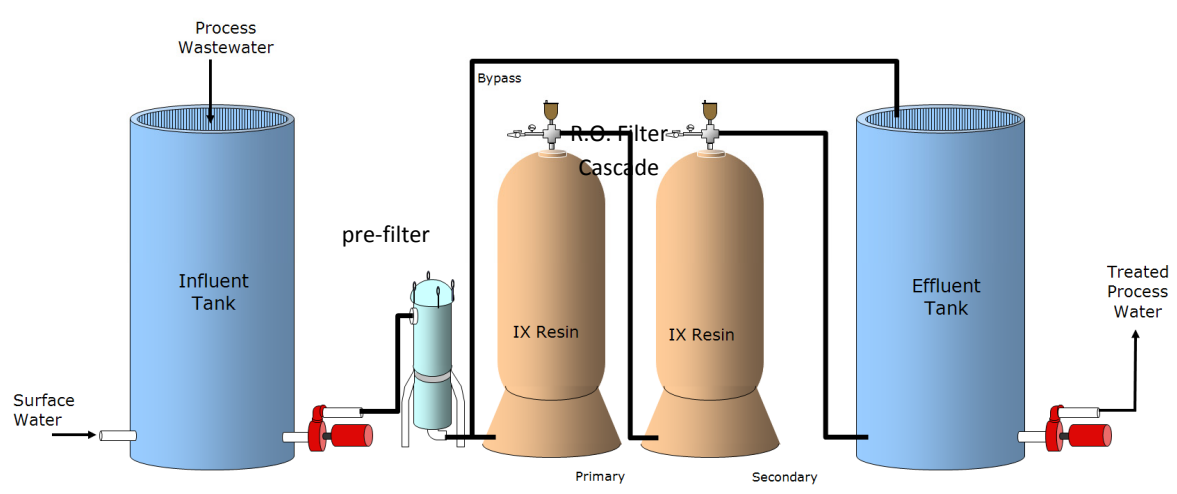

Figure 3: Ion Exchange treatment of process water. Surface water flows through cation and anion beds where contaminants are exchanged for $\mathrm{H}^{+}$and $\mathrm{OH}^{-}$ions. Pure water is the result, but the beds must be replaced when they fill up with contaminants and are depleted of $\mathrm{H}^{+}$and $\mathrm{OH}^{-}$ions. resources to facilitate a symbiotic design and operation. Ion-

exchange (deionization) and reverse osmosis were chosen to represent the most suitable options from the broad variety available. Assuming the use of these technologies in the discussions and

comparisons to follow is advantageous because they are easily scalable, well developed and understood, and easy to cost out for a variety of generic applications. Additional treatment options, not considered in this analysis, may also be required to address metals, biocides, organic material, microbial growth, particulates, and $\mathrm{pH}$.

As previously stated, the purpose of employing water treatment to cooling tower and hydrogen process discharge water is to increase the quality of the discharged water and/or decrease (ideally to zero) the volume of contaminated discharged water. Reverse osmosis systems separate the process flow into a "clean" stream and a "concentrated" stream. The "clean" stream typically has the higher flow rate, while the "concentrated" stream has a lower flow rate containing the bulk of impurities (Figure 2). This low volume, high concentration waste stream can be further treated or potentially discharged to the ocean or sanitary sewer as permits allow. Ion exchange systems remove the contamination from the flow stream (Figure 3). The contaminants in the water are adsorbed onto the ion exchange media, which is periodically disposed of or regenerated. For the purposes of this assessment, lon-exchange treatment is considered to be a "zero discharge" option (if disposal and regeneration are not considered) and reverse osmosis is considered a "low volume discharge" to the sanitary sewer (secondary treatment and re-use are not employed).

For both of the two technologies just described, at a given flow rate, the associated operational costs for consumables and power all increase with increasing TDS in the treatment influent stream and with decreasing treatment effluent discharge concentration limits. However, each treatment option has unique operational efficiency curves that make some scenarios more efficient for one than the other. For example, reverse osmosis systems may perform better at lower concentrations and higher flow rates, while ion-exchange systems are more efficient at removing contamination at higher concentrations and a longer residence time (lower flow rate). 


\section{Cooling Technologies:}

All envisioned hydrogen production technologies produce some waste heat. A few production pathways use reactors with large enough surface-to-volume ratios that they can be entirely air cooled, but most pathways use reactors that are large enough that they require higher heat transfer coefficients than aircooling can provide. These systems will use water as the primary coolant.

Cooling water is circulated from the process equipment, where its temperature increases as it absorbs energy, to the cooling equipment where its temperature falls as it releases energy to the environment. There are two types of cooling that are likely to be used in hydrogen production: cooling towers and dry cooling.

Cooling towers contact the warmed water directly with air. A small fraction of the water evaporates; this evaporative process leaves the remaining water much cooler. The evaporation also impacts water management: the evaporated water must be replaced from water taken from a water resource, and any dissolved solids that were in the water before it evaporated remain in the cooling loop. As the dissolved solids build up in the circulating water, they deposit on the equipment causing fouling, scaling and corrosion and loss of efficiency. In order to prevent these problems, some of the concentrate is removed from the system in a blowdown stream and as a result, more fresh water is required to keep the system operational. Furthermore, the blowdown must be disposed of.

Depending on the design of the cooling tower, the quality of the water resource and the constraints on waste water disposal, cooling towers may require treatment of the water used to replace evaporative and blowdown losses, and they may also require treatment of the blowdown itself (Figure 4).

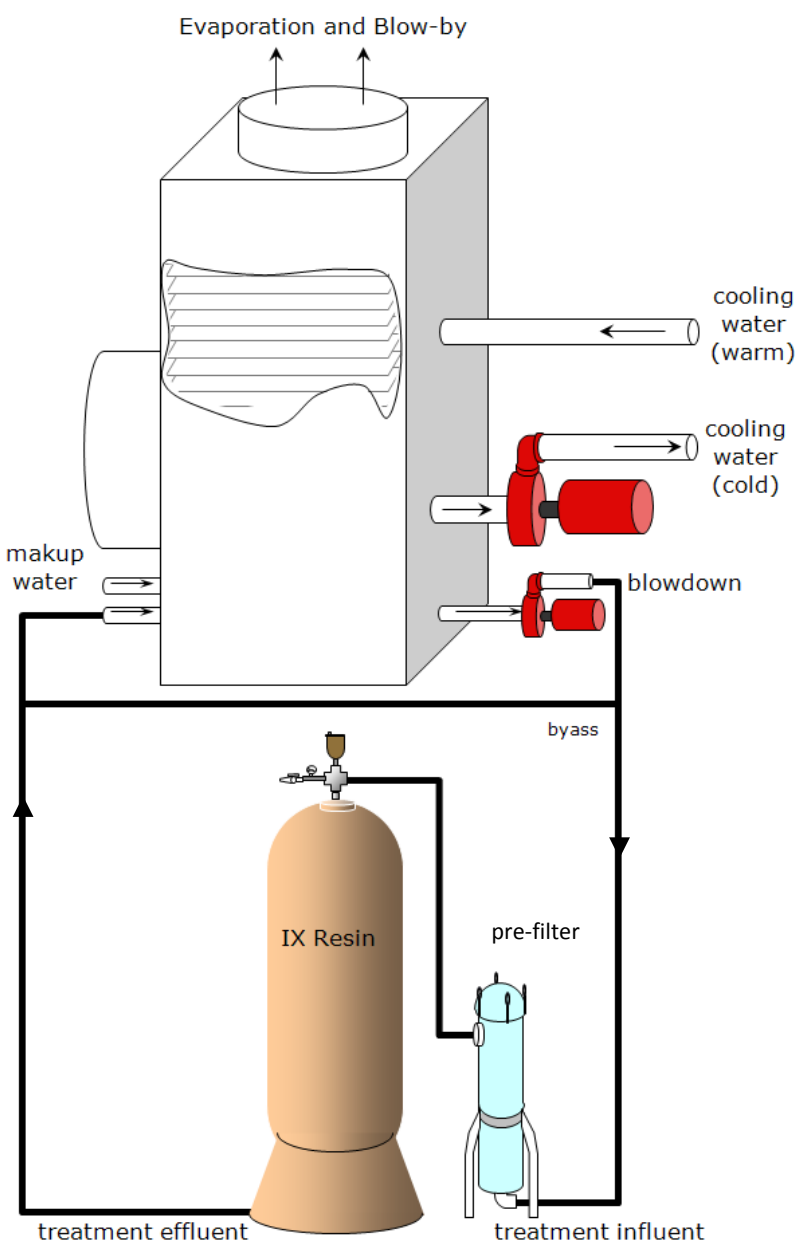

Figure 4: A zero-discharge wet cooling system. This system requires makeup water to replace evaporative and blow-by losses, but blowdown water is cycled through one or more ion exchange resins and returned to the tower. The resin(s) must be replaced periodically. 
Cooling towers also consume electricity in order to run the pumps that circulate the water and the fans that move the air. For the same cooling load, dry cooling systems are generally much larger, more capital intensive and have higher power consumption for pumps and fans.

Dry cooling systems, on the other hand, are completely sealed. Once filled with an initial charge of water, they never require makeup water and they create no wastewater. They use a heat exchanger (instead of a direct contactor) to reject heat from the water to the surrounding air. For the same cooling load, dry cooling systems are generally much more capital intensive and also have higher power draws for pumps and fans.

Dry cooling systems can cool the water to within several degrees of the absolute (dry bulb) temperature of the surrounding air. Cooling towers, on the other hand, can approach the humidity-dependent wet bulb temperature, which is always lower. The design of a cooling system is therefore dependent not only on the water supply and discharge constraints, but the expected temperature and humidity of the environment in which it is installed. Extremes in ambient temperature and humidity that exceed the design conditions can make some systems inapplicable and cause temporary de-rating or shutdown of others .

\section{Forecourt SMR:}

Current designs for forecourt SMR production of hydrogen incorporate direct air-cooled reactors. These systems therefore do not need cooling water, and only require process water. SMR requires process feedwater to have a TDS level of less than $100 \mathrm{ppm}$. Since forecourt production will not consume enough process water to warrant the dedicated infrastructure for drawing water from a surface or ground source, it is likely that these stations will be supplied with municipal water and will return wastewater to municipal sewers. Table 1 shows zero-discharge and non-zero discharge options for forecourt SMR. This table shows that zero discharge options become very expensive as water quality declines. The operating costs of zero discharge systems scale linearly with the amount of contaminants that must be removed. These data are also an example of the fact that reverse osmosis systems, while generally less expensive to operate than ion exchange systems, have greater power draw due to their high pressure pumping requirements.

\begin{tabular}{|l|c|c|c|c|c|c|}
\hline \multicolumn{4}{|c}{ Forecourt SMR Water Treatment Options: 1500 kg hydrogen per day, air cooling } \\
\hline Process Water Treatment & & lon Exchange & Reverse Osmosis & lon Exchange & Reverse Osmosis \\
\hline Zero Discharge? & & Yes & no & yes & no \\
\hline Water Resource (TDS, ppm) & & Municipal (400) & Municipal (400) & Well (1000) & Well (1000) \\
\hline Water Withdrawal & gpm & 6 & 7.8 & 6 & 7.8 \\
\hline Water Discharge & gpm & 0 & 1.8 & 0 & 1.8 \\
\hline Power Draw & $\mathrm{kW}$ & 0.22 & 2.27 & 0.24 & 2.27 \\
\hline Capital Cost & $\$$ & 274,000 & 24,000 & 796.000 & 25,000 \\
\hline Fixed O+M & $\$ / \mathrm{yr}$ & 8,700 & 8,700 & 8,700 & 8,700 \\
\hline Treatment Variable O+M & $\$ / \mathrm{kg}-\mathrm{H} 2$ & 0.50 & 0.02 & 1.45 & 0.02 \\
\hline
\end{tabular}

Table 1: Top level engineering and cost parameters for some water treatment options designed for forecourt SMR hydrogen production 


\section{Central SMR:}

Centralized steam methane reforming requires process and cooling water. Approximately 3.4 gallons of process water are sent to the boiler for every kilogram of hydrogen produced: half are consumed during the reforming and the other half are rejected from the boiler as process wastewater. For the 400,000 $\mathrm{kg}-\mathrm{H}_{2}$ /day plant described by $\mathrm{H} 2 \mathrm{~A}$, a cooling circulation rate of 40,000 gallons per minute is required to remove the excess heat generated by the process. The water consumption of the cooling system depends on the design (wet vs. dry, zero vs. non-zero discharge). Table 2 shows the required water flow rates for some of these combinations at a scale that matches H2A's "Current Central SMR without Sequestration," and draw water from a surface resource.

\begin{tabular}{|c|c|c|c|c|c|}
\hline \multicolumn{6}{|c|}{ Central SMR Water Treatment and Cooling Options: 379,387 kg hydrogen per day, no CCS } \\
\hline Cooling Method & & Tower & Tower & Dry & Dry \\
\hline Cooling Water Treatment & & Ion Exchange & none & $\mathrm{n} / \mathrm{a}$ & $\mathrm{n} / \mathrm{a}$ \\
\hline Process Water Treatment & & Ion Exchange & Reverse Osmosis & Ion Exchange & Reverse Osmosis \\
\hline Zero Discharge? & & Yes & No & Yes & No \\
\hline Water Resource (TDS, ppm) & & Surface $(800)$ & Surface (800) & Surface (800) & Surface (800) \\
\hline Water Withdrawal & gpm & 1202 & 2235 & 441 & 706 \\
\hline Water Discharge & gpm & 0 & 1033 & 0 & 265 \\
\hline Power Draw & $\mathrm{kW}$ & 1460 & 1146 & 3093 & 3227 \\
\hline Capital Cost & $\$$ & $117,100,000$ & $5,066,000$ & $63,4245,000$ & $14,100,000$ \\
\hline Fixed $\mathrm{O}+\mathrm{M}$ & $\$ / y r$ & 582,000 & 567,000 & 314,000 & 327,000 \\
\hline Treatment Variable $\mathrm{O}+\mathrm{M}$ & $\$ / k g-H 2$ & 0.84 & 0.03 & 0.38 & 0.01 \\
\hline
\end{tabular}

Table 2: Top level engineering and cost parameters for some cooling and water treatment options designed for central SMR hydrogen production

\section{Forecourt Electrolysis:}

Small electrolysis plants will reject heat in quantities comparable to forecourt SMR facilities. However, the heat transfer from electrolysis reactors is much slower than SMRs because electrolysis operates at much lower temperatures. Therefore electrolysis facilities require both process and cooling water. Electrolyzers are "dead end" devices for water: process water goes in, and only hydrogen and oxygen gases come out. The electrolyte is composed of water and a finely balanced mixture of solutes; contaminants that enter with process water cannot be purged without replacing the electrolyte. Therefore, electrolyzers require extremely pure process water - often with fractions of a part per million TDS. Both reverse osmosis and ion exchange systems can achieve this level of purification, but ion exchange systems are more common and are configurable for zero discharge. A 1,500 kg- $\mathrm{H}_{2} /$ day plant would require a cooling water circulation rate of 180 gallons per minute which could be accommodated by a cooling tower or dry cooling system. Table 3 describes these options. 


\begin{tabular}{|c|c|c|c|c|c|}
\hline \multicolumn{6}{|c|}{ Forecourt Electrolysis Water Treatment and Cooling Options: 1500 kg hydrogen per day } \\
\hline Cooling Method & & Cooling Tower & Cooling Tower & Dry Cooling & Dry Cooling \\
\hline Cooling Water Treatment & & none & none & none & none \\
\hline Process Water Treatment & & Ion Exchange & Reverse Osmosis & Ion Exchange & Reverse Osmosis \\
\hline Zero Discharge? & & No & No & Yes & No \\
\hline Water Resource (TDS, ppm) & & Municipal (400) & Municipal (400) & Municipal (400) & Municipal (400) \\
\hline Water Withdrawal & gpm & 8.0 & 8.8 & 2.1 & 2.9 \\
\hline Water Discharge & gpm & 0.9 & 1.74 & 0 & 0.84 \\
\hline Power Draw & $\mathrm{kW}$ & 7.0 & 8.6 & 18.8 & 20.4 \\
\hline Capital Cost & $\$$ & 162,000 & 58,000 & 328,000 & 224,000 \\
\hline Fixed O+M & $\$ / y r$ & 22,000 & 22,000 & 111,000 & 111,000 \\
\hline Treatment Variable $\mathrm{O}+\mathrm{M}$ & $\$ / k g-H 2$ & 0.22 & 0.02 & 0.21 & 0.01 \\
\hline
\end{tabular}

Table 1: Top level engineering and cost parameters for some cooling and water treatment options designed for forecourt electrolytic hydrogen production

\section{Central Electrolysis:}

Large electrolysis plants are likely to look like many small electrolysis plants running in parallel. They will require both process and cooling water, and can be serviced by both ion exchange and reverse osmosis treatment systems. Cooling will be handled by either towers or dry systems. Table 4 describes these systems.

\begin{tabular}{|c|c|c|c|c|c|}
\hline \multicolumn{6}{|c|}{ Central Electrolysis Water Treatment and Cooling Options: 52,300 kg hydrogen per day } \\
\hline Cooling Method & & Cooling Tower & Cooling Tower & Air Cooling & Air Cooling \\
\hline Cooling Water Treatment & & Ion Exchange & Reverse Osmosis & $\mathrm{n} / \mathrm{a}$ & $\mathrm{n} / \mathrm{a}$ \\
\hline Process Water Treatment & & Ion Exchange & Reverse Osmosis & Ion Exchange & Reverse Osmosis \\
\hline Zero Discharge? & & Yes & No & Yes & No \\
\hline Water Resource (TDS, ppm) & & Surface $(800)$ & Surface $(800)$ & Surface $(800)$ & Surface $(800)$ \\
\hline Water Withdrawal & gpm & 389 & 431.1 & 106 & 148.4 \\
\hline Water Discharge & gpm & 0.0 & 64.3 & 0.0 & 42.4 \\
\hline Power Draw & kW & 439 & 483 & 916 & 947 \\
\hline Capital Cost & $\$$ & $36,075,000$ & $1,440,000$ & $14,670,000$ & $3,765,000$ \\
\hline Fixed $\mathrm{O}+\mathrm{M}$ & $\$ / y r$ & 215,000 & 217,000 & 227,000 & 228,000 \\
\hline Treatment Variable $\mathrm{O}+\mathrm{M}$ & $\$ / k g-H 2$ & 1.86 & 0.03 & 0.60 & 0.01 \\
\hline
\end{tabular}

Table 2: Top level engineering and cost parameters for some cooling and water treatment options designed for central electrolytic hydrogen production

The quantities in tables 1 through 4 were derived from quotes and specifications provided by the equipment vendors in: Christian, 2009, Coker, 2009, Conservation, 2009, Cox, 2006, Hayward, 2009, Hudson, 2009, Luxx, 2009 Remco, 2009, and Siemens, 2009. 


\section{Engineering Economics of Water Systems for Hydrogen}

In planning a hydrogen production facility, stakeholders will seek to minimize costs under the constraints of local, regional and national ordinances. The hydrogen systems analysis team has shown that many factors influence the total cost of hydrogen: construction costs, energy costs, distribution infrastructure, taxes and incentives. While water is not expected to comprise a major fraction of the total cost of hydrogen (USDOE, 2003), it is still an important factor. For example, if local ordinances prohibit the discharge process wastewater to municipal sewers, a zero-discharge water treatment and cooling system will be required which will add both capital and operational costs to the plant.

A Microsoft Excel based modeling tool built on the foundation of $\mathrm{H} 2 \mathrm{~A}$ has been constructed to calculate these costs. The inputs to the tool are the cost of water delivered to the plant gate, the cost of water discharge to the sewer, and several water/cooling system parameters such as capital cost, power draw, operation and maintenance (O\&M) expenses and water intake and discharge flows. The tool is designed to integrate with the Hydrogen Program's Macro System Model (MSM).

\begin{tabular}{|c|c|c|c|c|c|c|c|}
\hline \multicolumn{8}{|c|}{ Water Purchase Price } \\
\hline \multirow{16}{*}{$\begin{array}{c}\text { Water } \\
\text { Discharge } \\
\text { Price }\end{array}$} & & $\$ 0.0001$ & $\$ 0.001$ & $\$ 0.01$ & $\$ 0.10$ & $\$ 1.00$ & \\
\hline & $\$ 0.0001$ & 1.356993 & 1.362263 & 1.414953 & 1.941862 & 7.21095 & \multirow{5}{*}{$\begin{array}{l}\text { Cooling } \\
\text { Tower, } \\
\text { Reverse } \\
\text { Osmosis }\end{array}$} \\
\hline & $\$ 0.001$ & 1.35815 & 1.363419 & 1.41611 & 1.943019 & 7.212107 & \\
\hline & $\$ 0.01$ & 1.369715 & 1.374985 & 1.427675 & 1.954584 & 7.223672 & \\
\hline & $\$ 0.10$ & 1.48537 & 1.490639 & 1.54333 & 2.070238 & 7.339326 & \\
\hline & $\$ 1.00$ & 2.641911 & 2.64718 & 2.699871 & 3.22678 & 8.495868 & \\
\hline & $\$ 0.0001$ & 1.955287 & 1.956871 & 1.97271 & 2.131106 & 3.715065 & \multirow{5}{*}{$\begin{array}{c}\text { Dry Cooling, } \\
\text { Deionization } \\
\text { Zero } \\
\text { Discharge }\end{array}$} \\
\hline & $\$ 0.001$ & 1.955287 & 1.956871 & 1.97271 & 2.131106 & 3.715065 & \\
\hline & $\$ 0.01$ & 1.955287 & 1.956871 & 1.97271 & 2.131106 & 3.715065 & \\
\hline & $\$ 0.10$ & 1.955287 & 1.956871 & 1.97271 & 2.131106 & 3.715065 & \\
\hline & $\$ 1.00$ & 1.955287 & 1.956871 & 1.97271 & 2.131106 & 3.715065 & \\
\hline & $\$ 0.0001$ & 1.384619 & 1.387154 & 1.412512 & 1.666089 & 4.20186 & \multirow{5}{*}{$\begin{array}{c}\text { Dry Cooling, } \\
\text { Reverse } \\
\text { Osmosis } \\
\text { Treatment }\end{array}$} \\
\hline & $\$ 0.001$ & 1.38557 & 1.388106 & 1.413464 & 1.667041 & 4.202812 & \\
\hline & $\$ 0.01$ & 1.395089 & 1.397624 & 1.422982 & 1.676559 & 4.21233 & \\
\hline & $\$ 0.10$ & 1.49027 & 1.492806 & 1.518163 & 1.77174 & 4.307511 & \\
\hline & $\$ 1.00$ & 2.442082 & 2.444618 & 2.469975 & 2.723552 & 5.259323 & \\
\hline
\end{tabular}

Table 3: The price of delivered hydrogen as calculated by H2A spreadsheets modified to account for water purchase and discharge prices and the varying capital and operating costs of different cooling and water treatment systems. The cells colored red indicate the lowest hydrogen price from among the three water-technology options.

The tool has been populated with an initial database of water system parameters relevant to the most likely hydrogen production pathways. The data are based on quotes from equipment vendors (Christian, 2009, Coker, 2009, Conservation, 2009, Cox, 2006, Hayward, 2009, Hudson, 2009, Luxx, 2009 Remco, 2009, and Siemens, 2009) and the framework is in place to add data for future production pathways such as nuclear and carbon capture enabled systems. 
Analysis shows that, as expected, when water prices rise, treatment and cooling methods with lower water inflow and discharge rates become economically attractive (Table 5). However, because water is such a small component of overall cost, water prices must rise by an order of magnitude from their current levels to encourage these technology shifts. More important will be water restrictions which push the effective price of water discharge to infinity. At this point, the amortized cost of a zerodischarge water system to the hydrogen production process becomes apparent. 


\section{Regional Water Stress and Hydrogen Production}

The mismanagement of water resources has affected nearly every region of the United States at some point in history. Certain regions continue to face water problems, while others appear to have implemented reasonably sustainable water infrastructure. One metric that may help to predict future constraints on water use is the "water stress" in a given region. In the most general sense, water stress is defined as water use divided by water supply. However, both "water use" and "water supply" are illdefined terms. Water use may be defined as the total amount of water withdrawn from all resources in a given region, or it may only refer to surface water or ground water. It might also only refer to consumptive use of water (water that is evaporated, chemically reacted or otherwise not returned to surface or groundwater resources). Similarly, water supply may refer to the total rainfall in a given region, or the rainfall in a region plus the net water influx to that region through rivers and streams.

EPRI (EPRI, 2003) published a report with county-by-county maps of multiple metrics of water stress in order to aid electricity producers anticipate difficulty in siting new power plants. That analysis is enhanced here by insights from stakeholders at the energy water nexus.

A map of water stress (Figure 5) was produced from a model developed at Sandia National Laboratories (Tidwell et. al, 2009). The model is capable of producing output at the county level, but because of the

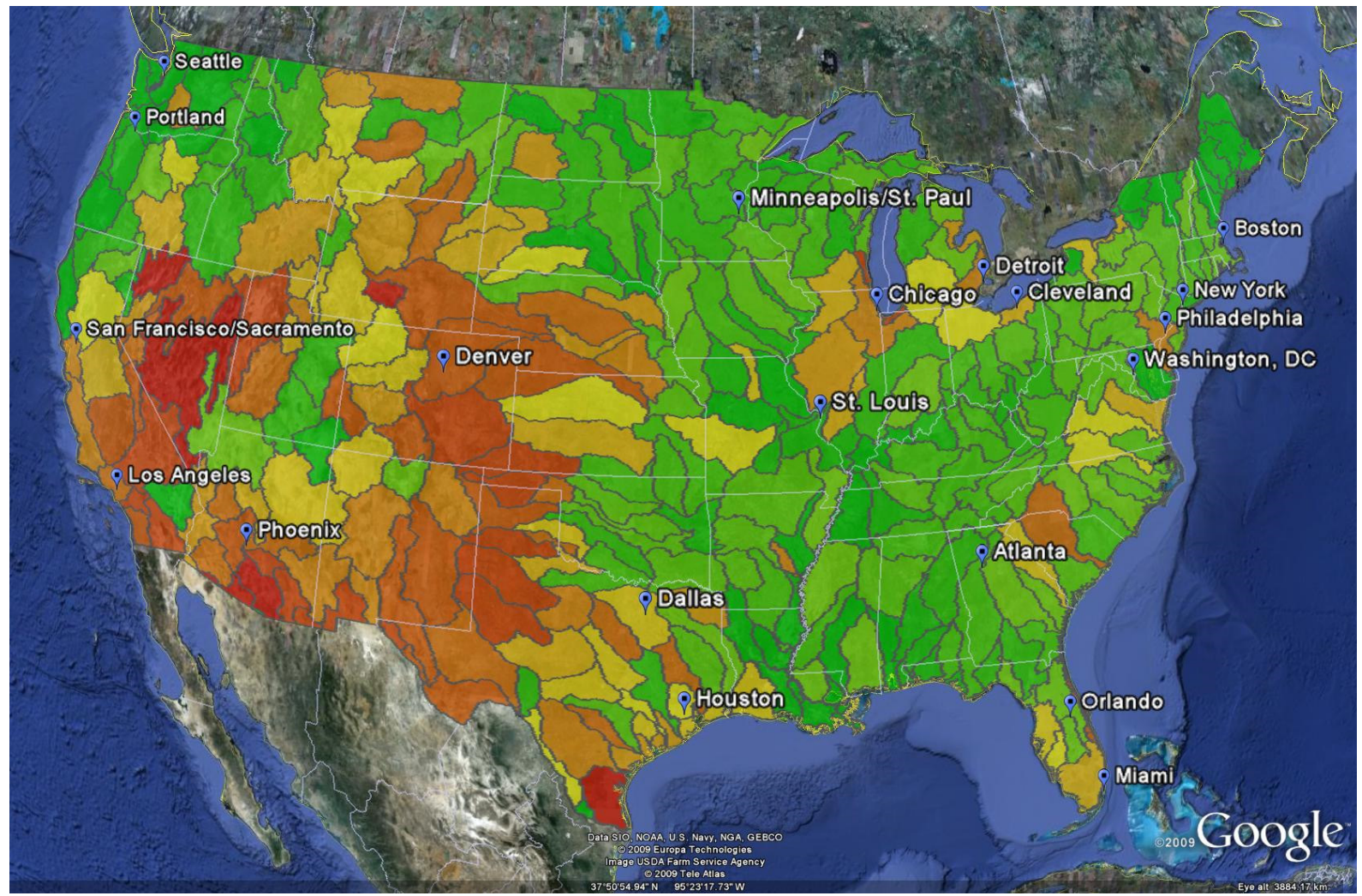

Figure 5: A Google Earth ${ }^{\mathrm{TM}}$ map of the United States showing 329 watersheds. The watersheds are color-coded by the level of water stress, defined as the total water withdrawals (ground plus surface water) divided by the total water influx (precipitation plus stream inflow). Red regions are more highly stressed. The metropolitan areas expected to see early hydrogen rollout are labeled. 
uncertainty in (and lack of) data on water transfers between counties, it is much more instructive to visualize the data at the watershed level. The model calculates ground and surface water supplies from precipitation and stream-gauge data published by the USGS, and accounts for inter-watershed transfers that are affected by upstream water consumption.

The model also calculates surface and ground water withdrawal for use in 6 economic sectors: municipal, industrial, agricultural, livestock, mining and electricity production. These data are collected at the county level by USGS, and are mapped into watershed units by assuming that counties that straddle multiple watersheds withdraw water proportional to the county area included in each watershed.

The model is capable of producing graphical output for ground water stress, surface water stress and total water stress. It is also capable of reporting numerical data for ground water, surface water and total water supply and use at the watershed level. Figure 5 shows total water stress defined as the sum of all annual water withdrawals in a watershed divided by the total naturally-occurring flow into surface and ground water resources.

Watersheds that are colored yellow have a water stress of approximately unity. This indicates that the total withdrawals are approximately equal to the naturally occurring influx of water. Watersheds with stress levels above one are not necessarily using water unsustainably; because approximately $3 / 4$ of all water that is withdrawn is returned to the surface (or aquifer), a water stress level (as defined above) of 4 can represent sustainable water use. On the other hand, irresponsible management of wastewater discharge can render some water resources unusable, significantly reducing the stress level at which problems arise.

Watersheds with extremely high levels of water stress are either importing water from neighboring watersheds or are depleting ground water stocks faster than those aquifers can be recharged. The exceptions to this rule are watersheds that border large bodies of fresh water (such as the great lakes) where the recharge rate of the lake is not accounted as a transfer to the watershed. These watersheds are functionally immune from actual water shortages, but (as history has shown) are vulnerable to water quality problems that arise from improper waste management.

Figure 5 not only shows water stress in the contiguous United States, but it also shows the metropolitan areas most likely to see a buildout of hydrogen infrastructure in the coming decades (Greene et. al, 2007). The extent to which hydrogen production and delivery affects water resources depends on the amount of water used (equal to the amount of hydrogen produced multiplied by the water intensity of hydrogen production) relative to the anticipated water use for other purposes. Under the most aggressive scenario (Phase III, Scenario 3) outlined in Green et. al, the water use dedicated to hydrogen as a percentage of overall water use and as a percentage of industrial water use is calculated. The results are reported in Table 6. 


\begin{tabular}{|c|c|c|c|c|c|}
\hline Metro Area & Watersheds & $\begin{array}{l}\text { Water } \\
\text { Stress }\end{array}$ & $\begin{array}{l}\text { Water used } \\
\text { for Hydrogen } \\
\text { (MGal/day) }\end{array}$ & $\begin{array}{l}\% \text { of supply } \\
\text { used for } \\
\text { hydrogen }\end{array}$ & $\begin{array}{l}\% \text { increase in } \\
\text { industrial } \\
\text { water usage }\end{array}$ \\
\hline New York & Lower Hudson & 0.04 & 15.6 & $0.02 \%$ & $16.1 \%$ \\
\hline Los Angeles & $\begin{array}{l}\text { Ventura-San Gabriel Coastal } \\
\text { Santa Ana }\end{array}$ & 2.01 & 12.3 & $1.14 \%$ & $7.1 \%$ \\
\hline Chicago & Upper Illinois & 1.17 & 8.9 & $0.08 \%$ & $0.8 \%$ \\
\hline Washington & Potomac & 0.09 & 7.5 & $0.02 \%$ & $6.8 \%$ \\
\hline $\begin{array}{l}\text { San Francisco/ } \\
\text { Sacramento }\end{array}$ & $\begin{array}{l}\text { San Francisco Bay } \\
\text { Lower Sacramento }\end{array}$ & 0.18 & 5.1 & $0.01 \%$ & $2.8 \%$ \\
\hline Philadelphia & Lower Delaware & 0.81 & 3.9 & $0.09 \%$ & $1.6 \%$ \\
\hline Boston & $\begin{array}{l}\text { Massachusetts- } \\
\text { Rhode Island Coastal }\end{array}$ & 0.05 & 8.4 & $0.05 \%$ & $20.6 \%$ \\
\hline Detroit & St. Clair-Detroit & 1.13 & 5.9 & $0.16 \%$ & $0.8 \%$ \\
\hline Dallas & Upper Trinity & 0.34 & 5.7 & $0.08 \%$ & $14.0 \%$ \\
\hline Houston & $\begin{array}{l}\text { San Jacinto } \\
\text { Galveston Bay-Sabine Lake }\end{array}$ & 0.27 & 5.4 & $0.08 \%$ & $2.5 \%$ \\
\hline Atlanta & $\begin{array}{l}\text { Altamaha } \\
\text { Apalachicola }\end{array}$ & 0.09 & 4.9 & $0.01 \%$ & $1.5 \%$ \\
\hline Miami & Southern Flordia & 0.44 & 1.4 & $0.02 \%$ & $5.5 \%$ \\
\hline Seattle & Puget Sound & 0.00 & 1.8 & $0.00 \%$ & $2.2 \%$ \\
\hline Phoenix & $\begin{array}{l}\text { Salt } \\
\text { Lower Gila-Agua Fria } \\
\text { Middle Gila }\end{array}$ & 4.88 & 2.8 & $0.44 \%$ & $44.0 \%$ \\
\hline $\begin{array}{l}\text { Minneapolis/ } \\
\text { St. Paul }\end{array}$ & $\begin{array}{l}\text { Upper Mississippi-Crow-Rum } \\
\text { Minnesota }\end{array}$ & 0.06 & 2.8 & $0.01 \%$ & $6.4 \%$ \\
\hline Cleveland & Southern Lake Erie & 0.33 & 2.3 & $0.04 \%$ & $1.5 \%$ \\
\hline Denver & South Platte & 8.75 & 2.5 & $0.66 \%$ & $5.0 \%$ \\
\hline St. Louis & $\begin{array}{l}\text { Upper Mississippi-Meramec } \\
\text { Lower Missouri }\end{array}$ & 0.01 & 2.4 & $0.00 \%$ & $6.2 \%$ \\
\hline Portland & $\begin{array}{l}\text { Willamette } \\
\text { Lower Columbia }\end{array}$ & 0.01 & 1.6 & $0.00 \%$ & $0.3 \%$ \\
\hline Orlando & $\begin{array}{l}\text { Kissimmee } \\
\text { St. Johns }\end{array}$ & 0.15 & 1.0 & $0.01 \%$ & $1.0 \%$ \\
\hline
\end{tabular}

Table 4: Metropolitan areas likely to roll out hydrogen with their relevant watersheds. Water stress is calculated as the sum of total water supply (ground and surface) in all relevant watersheds divided by the sum of total water withdrawal in those same watersheds. Water used for hydrogen was calculated by using the number of predicted $1500 \mathrm{~kg} / \mathrm{day}$ stations (Greene et. al, 2007) in each metro area and multiplying by a water intensive SMR-based hydrogen production technology (8.5 gallons withdrawal per kg hydrogen). The percent of supply used for hydrogen is calculated by dividing the water used for hydrogen by the total surface and groundwater supplies in the relevant watersheds. The percent increase in industrial water use is calculated by dividing the amount of water used for hydrogen by the watershed(s)wide industrial use of water. Zero-discharge and dry cooling technologies are capable of reducing these figures by a factor of 4. 


\section{Effects of Water on a Hydrogen Economy}

Table 7 shows the municipal water purchase and discharge prices ${ }^{1}$ for each region identified in Green et. al as well as the current forecourt SMR hydrogen price as predicted by the analysis tool developed with this report. The analysis used the default assumptions in H2A's forecourt SMR model and (conservatively) assumed the highest water intensity production technology. The variation in hydrogen prices is small, as was expected.

Analysis of the water prices, however, provides valuable information about the variability of water

\begin{tabular}{|l|c|c|c|}
\hline New York & $\begin{array}{c}\text { Water } \\
\text { Price } \\
\mathbf{( \$ / g a l )}\end{array}$ & $\begin{array}{c}\text { Sewer } \\
\text { Price } \\
\mathbf{( \$ / g a l )}\end{array}$ & $\begin{array}{c}\text { Hydrogen } \\
\text { Cost } \mathbf{( \$ / k g )}\end{array}$ \\
\hline Los Angeles & 0.0027 & 0.0043 & 2.1816 \\
\hline Chicago & 0.0032 & 0.0030 & 2.1877 \\
\hline Washington & 0.0015 & 0.0013 & 2.1780 \\
\hline San Francisco/Sacramento & 0.0034 & 0.0048 & 2.1860 \\
\hline Philadelphia & 0.0038 & 0.0094 & 2.1808 \\
\hline Boston & 0.0036 & 0.0046 & 2.1879 \\
\hline Detroit & 0.0047 & 0.0060 & 2.1938 \\
\hline Dallas & 0.0023 & 0.0053 & 2.1768 \\
\hline Houston & 0.0024 & 0.0038 & 2.1804 \\
\hline Atlanta & 0.0033 & 0.0038 & 2.1869 \\
\hline Miami & 0.0048 & 0.0126 & 2.1832 \\
\hline Seattle & 0.0021 & 0.0040 & 2.1779 \\
\hline Phoenix & 0.0047 & 0.0099 & 2.1870 \\
\hline Minneapolis/St. Paul & 0.0022 & 0.0025 & 2.1807 \\
\hline Cleveland & 0.0024 & 0.0036 & 2.1806 \\
\hline Denver & 0.0024 & 0.0050 & 2.1778 \\
\hline St. Louis & 0.0025 & 0.0020 & 2.1845 \\
\hline Portland & 0.0023 & 0.0035 & 2.1800 \\
\hline Orlando & 0.0036 & 0.0090 & 2.1800 \\
\hline Tab Wat & 0.0020 & 0.0052 & 2.1750 \\
\hline
\end{tabular}

Table 5: Water purchase price, water discharge price and the resultant hydrogen production cost calculated from H2A's default assumptions (including constant electricity price) for forecourt SMR production.

management nationwide.

Figure 6 plots the purchase price of water against the discharge price of water for all of the H2A regions as well as the cities sampled in by MWRA in 2008. There is little correlation between the price of water, and the price of wastewater management. In fact, the ratio of sewerage price to supply price can range between 0.65 and 3.0. It is likely that the cost of water services (acquisition and purification or treatment and disposal) is more closely linked to the age and state of water infrastructure in a region than it is to water scarcity or quality. Municipalities with newer infrastructure (whose debt must be paid down) or aging infrastructure (which requires expensive maintenance) may be passing their construction costs on to consumers. Locations which have recently upgraded supply but not wastewater systems (or vice versa) probably show the largest deviance from the mean. Because water

\footnotetext{
${ }^{1}$ Water prices can be difficult to compare between regions because different regions have different "tier" structures for water pricing, and because some regions have separate rate schedules for municipal and commercial/industrial customers while others do not. The table here was derived by calculating the average price per gallon for supply and sewerage of 90,000 gallons per year for a municipal (residential) customer. This is the same methodology used in the MWRA (Favaloro, 2008) analysis. When not available in the MWRA report, water prices, including tiered usage, were derived from the municipal water suppliers' websites listed in the references (Municipalities, 2009).
} 
utilities are regulated regional monopolies (and sometimes simply extensions of the municipal government), market forces cannot be expected to help predict these costs.

The correlation between water stress and water price is further evidence of this unpredictability. Figure 7 shows the regional water stress plotted against the price of municipal water supply. There is wide variability and if anything, a negative correlation between stress and price. A similar trend is seen in wastewater charges.
Purchase Price vs. Discharge Price

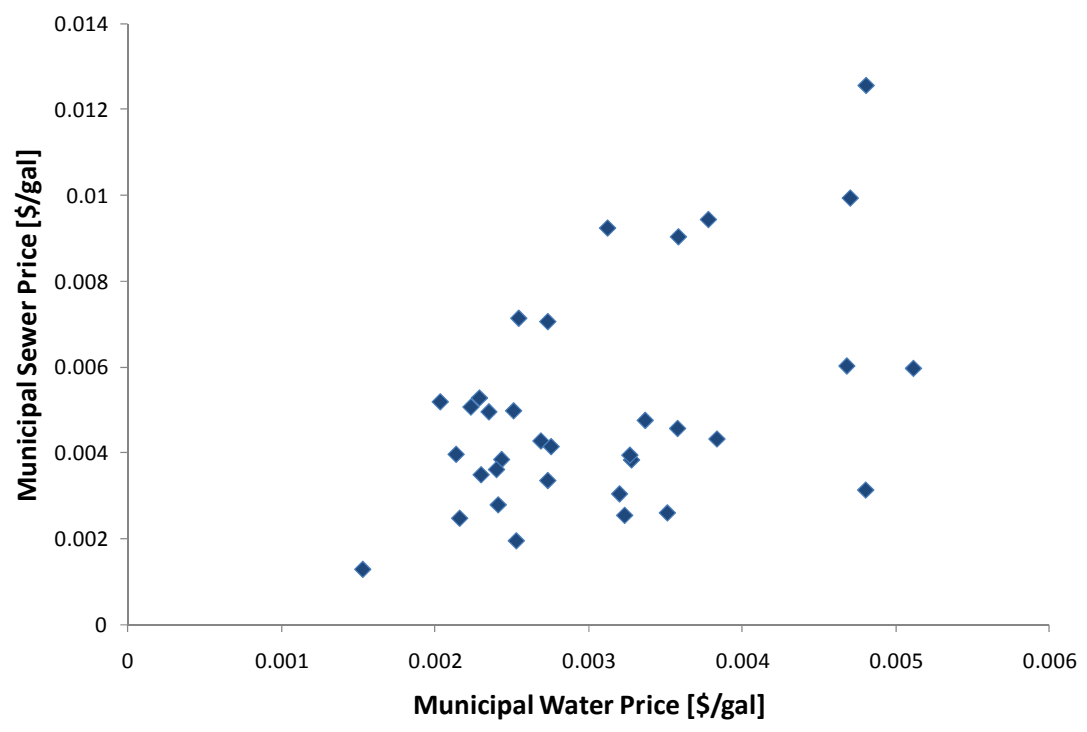

Figure 6: Water discharge (sewer) prices plotted against water purchase prices for 34 different municipalities. There is wide variability in water prices and little correlation between purchase and discharge prices.

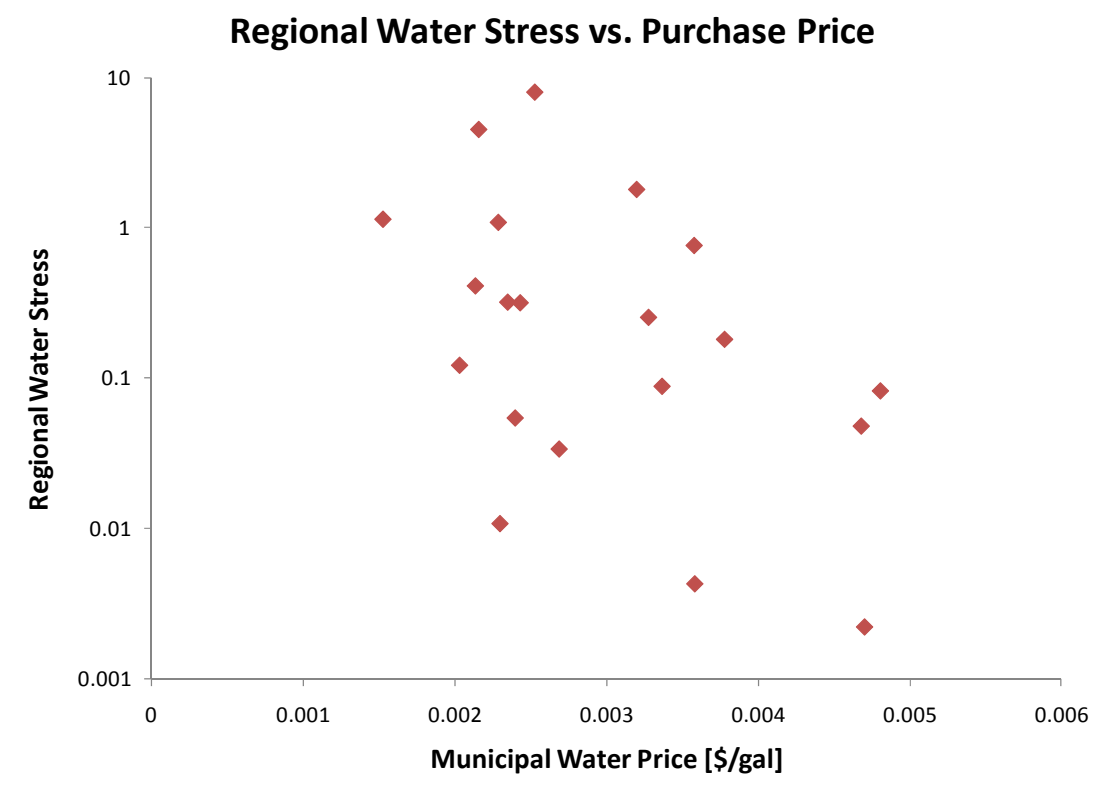

Figure 7: Regional water stress plotted against municipal water purchase price. There is little correlation between water stress and price, indicating that water scarcity is probably not the main driver of water prices. 


\section{Comparisons to Gasoline and Biofuels}

The analysis in this report represents a quantitative (and conservative) assessment of the impact of water resources on hydrogen facilities and of the impact of adding hydrogen production to water resources. However, adoption of hydrogen vehicles in this scenario would drive other displacements in the transportation system that would also affect (and be affected by) water resources.

The past few years have seen unprecedented change in U.S. transportation markets, policies and attitudes. The oil shock of 2004 -2008 persuaded consumers to drive fewer miles (DOT, 2009a) and to purchase more efficient automobiles (DOT, 2009b) ${ }^{2}$. Improved battery technologies have spurred the development of hybrid gasoline vehicles, and their success has prompted speculation that plug-in hybrids may soon become widely available. Government policies that encourage the use of corn ethanol have seen significant backlash from communities concerned about competition between food and fuel crops. Natural gas (an important hydrogen feedstock) prices rose with oil prices and then fell considerably when shale gas technology advanced. All the while, the economic crisis of 2008-2009 drove massive restructuring in the global automobile industry and severely impacted commodity and construction prices.

These market perturbations make it impossible to predict the overall water impact of hydrogen adoption. Do hydrogen vehicles displace conventional gasoline vehicles? Do they displace other advanced vehicles? Will biofuels policy evolve to support cellulosic ethanol, and at what rate will that technology become mature? Further compounding the ability to predict impacts are the different regional effects of biofuel and petroleum technologies. For example, ethanol's water footprint is largest at the farm where corn or switchgrass is grown, and that is likely to be broadly distributed over many watersheds in the Midwest. Gasoline's water footprint is actually largest at the oil field; U.S. water management policy is unlikely to affect the water requirements of overseas oil extraction. However refineries also use significant quantities of water, and unlike biomass crops, refineries are relatively tightly concentrated in a few watersheds (primarily New Jersey, the Gulf Coast and the West Coast). Therefore, hydrogen's net impact at both the national and regional level will depend heavily on

\begin{tabular}{|l|c|l|}
\hline Fuel & $\begin{array}{l}\text { Consumptive } \\
\text { Water Use }\end{array}$ & Notes \\
\hline $\begin{array}{l}\text { Gasoline } \\
\text { (gal } \mathrm{H}_{2} \mathrm{O} / \text { gal gasoline) }\end{array}$ & $1.75-2$ & $\begin{array}{l}\text { refining only, no exploration and } \\
\text { production }\end{array}$ \\
\hline $\begin{array}{l}\text { Corn Ethanol } \\
\text { (gal } \mathrm{H}_{2} \mathrm{O} / \text { gal ethanol) }\end{array}$ & $10-324$ & $\begin{array}{l}\text { high consumption due to crops } \\
\text { that require irrigation }\end{array}$ \\
\hline $\begin{array}{l}\text { Switchgrass Ethanol } \\
\text { (gal } \mathrm{H}_{2} \mathrm{O} / \text { gal ethanol) }\end{array}$ & $1.9-9.8$ & \\
\hline $\begin{array}{l}\text { SMR Hydrogen } \\
\text { (gal } \mathrm{H}_{2} \mathrm{O} / \mathrm{kg} \text { hydrogen) }\end{array}$ & $4.5-5.1$ & \\
\hline $\begin{array}{l}\text { Electrolysis Hydrogen } \\
\text { (gal } \mathrm{H}_{2} \mathrm{O} / \mathrm{kg} \text { hydrogen) }\end{array}$ & $12.5-64$ & $\begin{array}{l}\text { high range in areas with high } \\
\text { water-consumption electricity mix }\end{array}$ \\
\hline Table 6: Consumptive water use ranges for the manufacture of various fuels
\end{tabular}

\footnotetext{
${ }^{2}$ Based on the share of light trucks in new vehicle sales.
}

everything else going on in the transportation sector. Wu et. al (2009) provides estimates of lifecycle water impacts of biomass and gasoline. Those estimates are compared with this analysis of hydrogen's water impacts in Table 8. 


\section{Conclusions}

Water is a critical, but relatively low cost, feedstock for hydrogen production. It is possible, but unlikely, that the cost of water will determine the feasibility of a hydrogen production or distribution facility. Similarly, certain locations will see a significant rise in their industrial water usage if hydrogen is produced there, but the overall impacts on water availability should be minimal.

Nonetheless, stakeholders in the hydrogen industry should be aware of water constraints. In particular, no previous studies have examined wastewater management for hydrogen. While the engineering challenges for cooling tower blowdown and process water discharge are not expected to be any more difficult for hydrogen than for any other industrial commodity, planners can use the analysis outlined here to estimate costs for zero and non-zero discharge systems. The analysis described here represents an integration of H2A (USDOE, 2003), Sandia's Decision Support Model (Tidwell, 2009), HyDRA (USDOE, 2006) and the Macro System Model (USDOE, 2007b). These tools are available (at various levels of abstraction) to stakeholders in the hydrogen industry.

Locations where hydrogen production increases the demand for industrial water by a significant amount (New York, Boston, Dallas, Phoenix) may have policies that are unfriendly to water-consuming industry. However, it is impossible to predict with any certainty how water policy will develop in any location. Similarly, particularly high water prices are a "red flag" for certain regions (San Francisco, Boston, Atlanta, Seattle, Portland) in the near-term and regions with high water stress (Los Angeles, Phoenix and Denver) are riskier in the long term.

Water is abundant. It is instructive to remember that in the U.S., we have an infrastructure that annually handles about 100 million metric tons (MMT) of cement, about the same amount of steel, 300 MMT of corn, 500 MMT of natural gas and 1000 MMT each of coal and oil (PCA, 2009, USGS, 2008, CRA, 2009, and USDOE, 2009). We manage about 500,000 MMT of fresh water (Solley, 1999, Hutson, 2004 and Kenny, 2009) - a scale greater than any other commodity by more than two orders of magnitude. Management at this scale continues to provide procurement, distribution, waste management and policy challenges, but we have shown time and again that we can meet them. Hydrogen fuel for transportation provides multiple options for water management at reasonable costs. 


\section{References}

Brooks, D, 2002, Water, LOCAL-LEVEL MANAGEMENT, International Development Research Centre, Ottowa (Brooks, 2002)

Christian Power Equipment, 2009, Personal Communication (Christian, 2009)

City Of Hayward, CA, 2009, Special industrial sanitary sewer discharge formulary (Hayward, 2009)

Coker Pump \& Equipment Company, 2009, Personal Communication (Coker, 2009)

Conservation Mechanical Systems Inc., 2009, Personal Communication (Conservation, 2009)

Corn Refiner's Association, 2009, U.S. Corn Production Statistics Available at:

http://www.corn.org/uscprod.htm (CRA, 2009)

Cox, R., Cooling Tower Energy \& Operating Cost Analysis Software, 2006, TowerTech Inc. (Cox, 2006)

EPRI, 2003, A Survey of Water Use and Sustainability in the United States With a Focus on Power Generation: Palo Alto, 1005474 (EPRI, 2003)

Favaloro, J.E., 2008, Annual Water and Sewer Retail Rate Survey: MWRA Advisory Board (Favaloro, 2008)

Greene, D.L., Leiby, P.N., James, B., Perez, J., Melendez, M., Milbrandt, A., Unnasch, S., Rutherford, D., Hooks, M., 2007, Analysis of the Transition to Hydrogen Fuel Cell Vehicles and the Potential Hydrogen Energy Infrastructure Requirements: Oak Ridge National Laboratory ORNL/TM-2008/30 (Greene et. al, 2007)

Hudson Products Corporation, 2009, Personal Communication (Hudson, 2009)

Hutson, S.S., Barber, N.L., Kenny, J.F., Linsey, K.S., Lumia, D.S., and Maupin, M.A., 2004, Estimated use of water in the United States in 2000: Reston, Va., U.S. Geological Survey Circular 1268 (Hutson et. al, 2004)

Kenny, J.F., Barber, N.L., Hutson, S.S., Linsey, K.S., Lovelace, J.K., and Maupin, M.A., 2009, Estimated use of water in the United States in 2005: U.S. Geological Survey Circular 1344 (Kenny et. al, 2009)

Luxx Ultra-Tech, Inc., 2009, Personal Communication (Luxx, 2009) 
Municipal Water District Websites, 2009 (Municipalities, 2009):

http://egov.cityofchicago.org/

http://www.atlantawatershed.org/custsrv/Rate/2008-09 to 2012 Rates \& Bill Calc.pdf

http://www.miamidade.gov/wasd/rates.asp

http://www.phoenix.gov/WATER/wtrswrrates.html

http://www.clevelandwater.com/Resident/rates.aspx

http://www.neorsd.org/rates.php

http://www.denverwater.org/BillingRates/RatesCharges/2009Rates/InsideCity/

http://pwwmd.denvergov.org/customerservice/

http://www.portlandonline.com/water/index.cfm?c=29415

http://www.portlandonline.com/bes/index.cfm?c=47683\&a=199690

http://www.orangecountyfl.net/cms/DEPT/utilities/rates_fees.htm

Remco Engineering, 2009, Personal Communication (Remco, 2009)

Portland Cement Association, 2009, Overview of the Cement Industry, Available at:

http://www.cement.org/basics/cementindustry.asp (PCA, 2009)

Siemens Water Technologies Corp.,2009, Personal Communication (Siemens, 2009)

Solley, W.B., Pierce, R.R., Perlman, H.A., 1999, Estimated use of water in the United States in 1995:

Reston, Va., U.S. Geological Survey Circular 1200 (Solley et. al, 1999)

Tidwell, V.C., Kobos, P.H., Malczynski, L., Klise, G., Hart, W.E., and Castillo, C., 2009, Decision Support for Integrated Water-Energy Planning, Sandia Report : SAND2009-6521 (Tidwell et. al, 2009)

Wu, M., Mintz, M., Wang, M., and Arora, S., 2009, Consumptive Water Use in the Production of Ethanol and Petroleum Gasoline: Center for Transportation Research, Energy Systems Division, Argonne National Laboratory, ANL/ESD/09-1 (Wu et. al., 2009)

U.S. Department of Energy, Hydrogen Program, 2003 - 2009, The Hydrogen Analysis (H2A) Project, Available at: http://www.hydrogen.energy.gov/h2a_analysis.html (USDOE, 2003)

U.S. Department of Energy, National Renewable Energy Lab, 2006 - 2009, HyDRA, Hydrogen Demand and Resource Analysis Tool, Available at: http://rpm.nrel.gov/ (USDOE, 2006)

U.S. Department of Energy, Offices of Energy Efficiency and Renewable Energy, 2007, Hydrogen, Fuel Cells \& Infrastructure Technologies Program Multi-Year Research, Development and Demonstration Plan available at: http://www1.eere.energy.gov/hydrogenandfuelcells/mypp/ (USDOE, 2007a)

U.S. Department of Energy, Offices of Energy Efficiency and Renewable Energy, 2007, Macro-System Model Progress Report, available at:

http://www.hydrogen.energy.gov/analysis_repository/project.cfm/PID=66 (USDOE, 2007b) 
U.S. Department of Energy, Energy Information Administration, 2009, Annual Energy Review2008: DOE/EIA-0384(2008) (USDOE, 2009)

U.S. Department of Transportation, 2009, Federal Highway Administration's Traffic Volume Trends, available at: http://www.fhwa.dot.gov/ohim/tvtw/tvtpage.cfm (USDOT, 2009a)

U.S. Department of Transportation, 2009, Bureau of Transportation Statistics: New and Used Passenger Car Sales and Leases, available at:

http://www.bts.gov/publications/national_transportation_statistics/html/table_01_17.html

U.S. Geological Survey, Commodity Statistics, Mineral Commodity Summaries for Iron and Steel, 2008, Available at: http://minerals.usgs.gov/minerals/pubs/commodity/iron_\&_steel/festemcs07.pdf (USGS 2008) 